\title{
The Effects of the Atmosphere of the Heat Treatment on the Colour of CdS
}

\author{
Makoto Tsunashima* and Kenzo MoHrI* \\ Mitsubishi Metal Corporation*
}

\begin{abstract}
The effects of the atmosphere of the heat treatment on the colour of CdS were studied.

Original sample is CdS powder $99.999 \%$ of purity. It was heat-treated under the four atmospheres, and treated in a nitric acid solution.

The lattice constant, particle size and spectral reflectance curves of these treated specimens were measured.

As the results, CdS showed remarkably an increase of the rising slope of spectral curve and more brightness in color than other samples by the heat treatment in an atmosphere of oxygen, and meanwhile, it gave a tendency of dark reddening in nitrogen, in vacuo and in sulfur. An increase of hexagonality and particle size were promoted in the presence of sulfur.

Therefore, it is assured that the existance of oxygen in an atmosphere affects to brighten the colour of CdS.
\end{abstract}

\footnotetext{
* Kitabukuro-machi, Omiya City, Saitama, Japan
} 


\title{
CdS の加熱処理ふん囲気の色調におよぼす影響
}

\author{
綱 島 真*.毛利憲 三*
}

要旨

カドミウム系顔料の一品種であるところの CdS に関して，焼成ふん囲気の色調に和よ ぼす影響を検討した。

試料としては高純度 CdS (99.999\%) を使用し，これを種々の条件で加熱処理した。

これら処理試料に対して結晶多形，格子定数，粒子径ならびに分光反射率曲線などを測 定した。

以上の結果, CdS を加熱処理するふん囲気として酸素が存在するとさは, 分光曲線の吸 収端の立上りこう配が大きくなるとともに色調は他の試料に比較して著しく鮮明となるこ とが示された。また, らん囲気が窒素, 隇圧さらにイオウの場合は, 立上りこう配が小さ くなり，色調も暗赤色化していくことが見いだされた。六方度と粒子径の増加はイオウふ ん囲気の場合に著しく促進された。

したがって，原理の解明はできなかったが，CdS の鮮明な色調のものを得るためには酸 素の存在がきわめて有効であることが見いだされた。

\section{1. 緒言}

カドミウム系顔料の色調と特性に関しては多くの研 究, 報告がある1) 8)。それらのらち, CdS 組成の顔料に 関しては佐藤1), また CdS-CdSe 組成に関しては Eroles ら年るいは山内ら ${ }^{3)}$, さらに $\mathrm{CdS}-\mathrm{ZnS}$ 組成に関しては

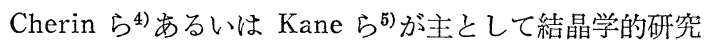

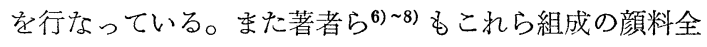
般にわたって製造工程の解析と色調変化の原因解明を行 なってきた。

一方, これらの研究に関連して CdS, CdSe なとの化 合物の非化学量論性, 特よび結晶表面あるいは内部の酸 素に関する研究も行なわれている。特に CdS 単結晶に ついては酸素が $\mathrm{CdS}$ 結晶内に入り,電気特性なぞに影響 を特よぼすことが報告されている9 柱)。また Däweritz ら ${ }^{14)}$ は CdSe に関し, Ludeke ${ }^{15)}$ はII-VI化合物全般に わたって同様な研究を報告している。CdS の組成が化学 量論的当量から主として Cd 過剩になっていることは, Hàrsy $ら^{16)}$, Clark ら ${ }^{17)}$ とり, 同じくCdSe に関して

昭和 48.12 .17 受理

* 三菱金属株式会社大宮工場

埼玉県大宮市北袋町 1-297

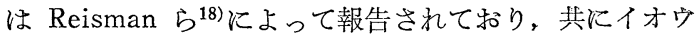
あるいはセレンの空孔によるものとのべている。

以上のべたような研究経緯を総合すれば, CdS の色調 拉よび諸特性はイオウあるいは酸素のわずかな量によっ て变化することが推察できる。したがって本報告では, $\mathrm{CdS}$ の色調に対するイオウと酸素の影響を検討するた め, 色調が最も大きな影響を受ける加熱処理ふん囲気の 効果を追求した。

\section{2. 実 験 方 法}

\section{1 試 料}

原試料は 99. 999\% の高純度 $\mathrm{CdS}$ 粉末を用いた。粒 子は電子顕微鏡写真拉よび窒素ガス吸着法による比表面 積径の測定によると，ほぼ均一で約 $170 \mathrm{~m} \mu$ の大きさを もっている。結晶形は Short ら ${ }^{19)}$ の式の修正式 ${ }^{81}$ とり 粉末 X線回析図から算出すると, 六方度（結晶全体に占 める六方晶の割合) は約 $20 \%$ となった。これから原試 料は低温安定形の立方晶に近いものといえる。

試料は $10 \mathrm{~g}$ を内容積約 $40 \mathrm{cc}$ の石英管に入れ, ふん 囲気を調整した後加熱処理を行なった。

\section{2 処理条件}

加熱処理の詳細な条件は表-1 に示した。前处理はす 
Table 1. Conditions of heat treatment of $\mathrm{CdS}$

\begin{tabular}{|c|c|c|c|c|c|c|c|}
\hline \multirow{2}{*}{ Sample } & \multirow{2}{*}{ Pretreatment } & \multicolumn{3}{|c|}{ First treatment } & \multicolumn{3}{|c|}{ Second treatment } \\
\hline & & Temperature & Time & Atmosphere & Temperature & Time & Atmosphere \\
\hline A & $\begin{array}{c}200^{\circ} \mathrm{C} \\
10^{-3} \mathrm{mmHg} \\
60 \mathrm{~min} .\end{array}$ & $700^{\circ} \mathrm{C}$ & $60 \mathrm{~min}$ & $\mathrm{O}_{2}$ & 一 & - & 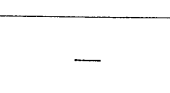 \\
\hline $\mathrm{B}$ & "I & $\prime \prime$ & "I & $\mathrm{N}_{2}$ & - & - & - \\
\hline C & " & " & "1 & $S * 1$ & - & - & - \\
\hline $\mathrm{D}$ & "l & " & $" \prime$ & $10^{-3} \mathrm{mmHg}$ & - & - & - \\
\hline $\mathrm{AC}$ & " & " & " & $\mathrm{O}_{2}$ & $700^{\circ} \mathrm{C}$ & $30 \mathrm{~min}$. & $S^{* 2}$ \\
\hline$B$ A & "l & $" \prime$ & "1 & $\mathrm{N}_{2}$ & "II & "I & $\mathrm{O}_{2}$ \\
\hline $\mathrm{CA}$ & $" 1$ & "l & " & $S * 1$ & "I & 11 & $\prime \prime$ \\
\hline D A & " & "1 & " & $10^{-3} \mathrm{mmHg}$ & " & $\prime \prime$ & "l \\
\hline
\end{tabular}

*1 $1 \%$ Sulfur powder admixed to original sample

to first heat-treated sample

べて $200^{\circ} \mathrm{C}, 10^{-3} \mathrm{mmHg}$ にて 1 時間行なった。つづい て試料管内のふん囲気を所定のガスで満たし，所定の温 度に昇温後試料管内が大気圧と平衡になった後、コック る閉めて管を密封状態で所定時間加熱を行なった。した がって加熱処理は注ぼ大気圧で行なわれているとい光 る。第 1 段階と第 2 段階の加熱処理の中間に括いて試料 を一度 $200^{\circ} \mathrm{C}$ で 5 分脱気を行ない, 第 2 段階のふえ囲気 ガスを導入後所定温度に昇温した。表- 1 には温度 $700^{\circ} \mathrm{C}$ の場合の条件を示したが， $500^{\circ} \mathrm{C}$ 扣よび $600^{\circ} \mathrm{C}$ の場合る これに準じた処理条件である。

試料をイオウふん囲気で加熱処理する場合，イオウの 沸点は $445^{\circ} \mathrm{C}$ で気化するので本実験の最低処理温度 500 ${ }^{\circ} \mathrm{C}$ に招いてもふん囲気ガスとなっている。イオウふん囲 気は試料中にあらかじめ粉末イオウを混合して和き，加 熱処理を窒素ふん囲気中で行ならことによってイオウを 気化させて得た。このときのイオウ分圧に関するイオウ の量は，すで飞報告8)したように試料 CdS 飞 1 重量\%で も著しい効果を示すとともに，200 $\mathrm{C}, 10^{-3} \mathrm{mmHg}$ の脱 気（前処理）の段階では飛散は湾とんどないので本実験 でも 1 重量\%とした。混合の度合は穾質的にはガス化す ることを考元て，乳錸中で 5 分間混合するにとどめた。

さらに, これらの加熱处理試料は $\mathrm{pH} 3$ の硝酸水溶液 $500 \mathrm{cc}$ 中に $10 \mathrm{~g}$ を入れて 10 分間煮沸し, 洗浄, 乾燥 後各種測定に供した。これによって酸化カドミウム, 硫 酸カドミウムなぞの可溶性塩類を除去できる。

\section{3 処理試料の特性の測定}

処理試料の諸特性は次のような方法で測定した。

色調は分光光度計（日立製作所製 EPR-2 型）によっ て分光反射率曲線を測定した。さらにこれから CIE 表 示法 ${ }^{200}$ とよる特性值を算出した。

結晶構造に関してはX線回折計（フィリップ社製）を
用いて解析した。測定は $\mathrm{Cu}-\mathrm{K}_{\alpha}$ 線 ( $\mathrm{Ni}$ フィルター), 管電圧 $30 \mathrm{kV}$, 管電流 $20 \mathrm{~mA}$, 走査速度 $1^{\circ} /$ 分, 発散スリ ット $1^{\circ}$, 受光スリット $0.2 \mathrm{~mm}$, 時定数 1 秒の条件で行 なった。また格子定数はデバイーシェラーカメラを用い て測定したフィルムから最少 2 乗法を用いて算出した。

粒子表面の官能基の差をみるため, 赤外分光光度計 （日本分光製 DS-402G 型）を用いて，KBr 錠剤法によ って調製した試料を測定した。

粒子の形と大きさは日本電子製 $\mathrm{T}-6 \mathrm{~S}$ 型電子顕微鏡 を用い,カーボンレプリカ法によって作成した試料を写 真撮影した。また液体窒素温度に特ける窒素ガス吸着法 を用いて，BET 法によって表面積径を算出した。

ガス分析は定容測圧型（離合社製）のガス分析計によ って行なった。前処理は室温で $10^{-5} \mathrm{mmHg}$ にて脱ガス した。これを $500^{\circ} \mathrm{C}$ に加熱昇温したときの脱着ガスを定 量した。

化学分析は $\mathrm{Cd}$ 飞対しては EDTA 滴定法, S 亿対し ては重量法によって行なった。

\section{3. 実 験 結 果}

\section{1 加熱処理-ふん团気の色調への影響}

原試料の CdS を表-1 に示したように酸素，窒素，イ オウ特よび滅压の 4 種ふん囲気中で $700^{\circ} \mathrm{C} ， 1$ 時間加熱 処理し，さらに硝酸処理した試料の分光反射率曲線を 図-1 亿示す。また表-2 にはこ礼ら試料の CIE 表示法に よる特性值を示す。

これらの結果から, 加熱処理のふえ囲気を変えた 4 種 の試料（A～D）の色調（特に鮮明度*を表わす刺激純

*色調の刺激純度の大きさ, あるいは分光曲線のこう 配の大なることをここでは色調が鮮明であるという 表現で示した。 
Table 2. Some characteristics of heat-treated $\mathrm{CdS}$ powders at $700^{\circ} \mathrm{C}$

\begin{tabular}{c|c|c|c|c|c|c|c|c|c|c}
\hline \multirow{2}{*}{ Sample } & \multicolumn{3}{|c|}{ Colour*1 } & \multicolumn{2}{|c|}{ Lattice constant (A) } & \multicolumn{2}{c|}{ Separated gas (ppm) } & hexagonality & \multirow{2}{*}{ S/Cd } \\
& $\lambda_{d}$ & $P_{e}$ & $Y$ & $a_{0}$ & $c_{0}$ & $\mathrm{O}_{2}$ & $\mathrm{~N}_{2}$ & $\mathrm{H}_{2}$ & & \\
\hline $\mathrm{A}$ & 579.7 & 89.2 & 63.4 & 4.136 & 6.720 & 100 & 7 & - & & 0.99 \\
$\mathrm{~B}$ & 582.8 & 87.9 & 54.1 & 4.137 & 6.720 & 50 & 5 & 4 & & 0.99 \\
$\mathrm{C}$ & 584.2 & 84.2 & 36.4 & 4.135 & 6.719 & 30 & 2 & 7 & & 0.99 \\
$\mathrm{D}$ & 583.8 & 87.2 & 47.9 & 4.139 & 6.720 & 40 & 7 & 5 & & 0.98 \\
\hline
\end{tabular}

*1 CIE colour system, $\lambda_{d}$ : dominant wavelength, $P_{e}$ : excitation purity, $Y:$ lightness.

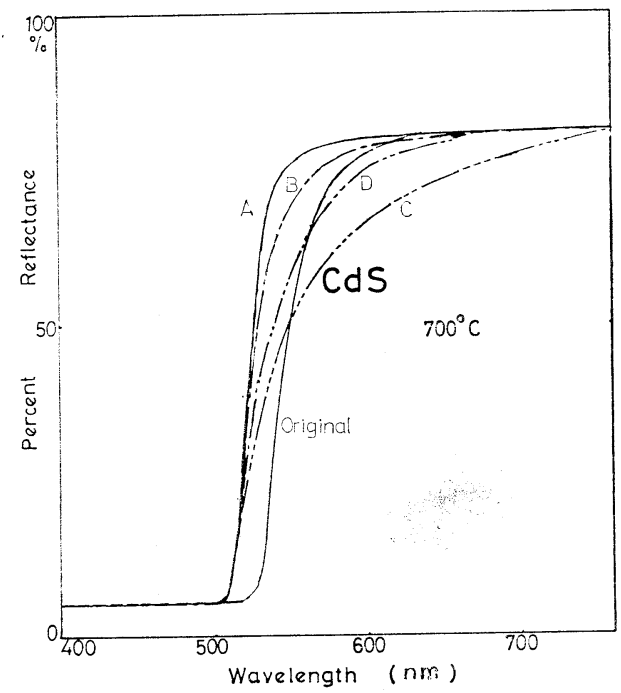

Fig. 1. Spectral reflectance curves of heat-treated $\mathrm{CdS}$ specimens at $700^{\circ} \mathrm{C}$

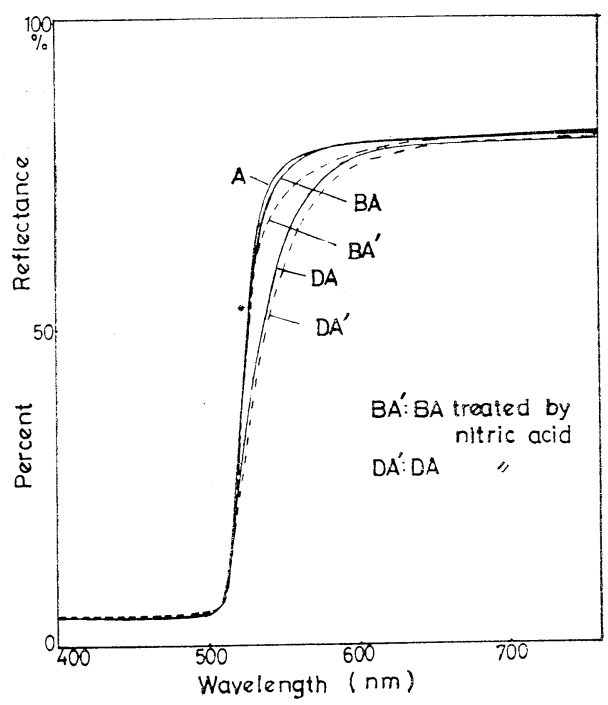

Fig. 2. Differences of Spectral reflectance curves between before and after nitric acid treatment
度 $\mathrm{Pe}$ ）が著しく異なり, 酸素, 窒素, 減圧, イオウの 順に暗赤色化していくことが明らかとなった。 次に表-1 の 2 次加熱処理した試料についてのベる。 これら試料に酸処理を行なうと図一2に示したように酸 処理後に拉いて色調が 1 次加熱処理試料の色調にもどる 傾向がみられた。これは酸処理によって主として微少粒 子あるいは粒子表面などふん囲気の影響を受けやすい部 分が溶解除去されたためといえる。図示しなかった試料 も全く同じ結果であるが，図が判別しにくくなるため省 略した。

次に図-3には 1 次および 2 次加熱処理の試料間の比 較を示した。この結果, ふん囲気の色調に対する効果は 1 次処理の場合とまったく同じ傾向を示し, 鮮明度は酸 素によって大きくなり，滅圧，イオウによって小さくな った。

以上のように加熱処理のふん囲気は未処理試料の履歴 扣よび結晶性によって多少の影響を受けるが，最終的に は色調（特に鮮明度）を規制することがわかった。この

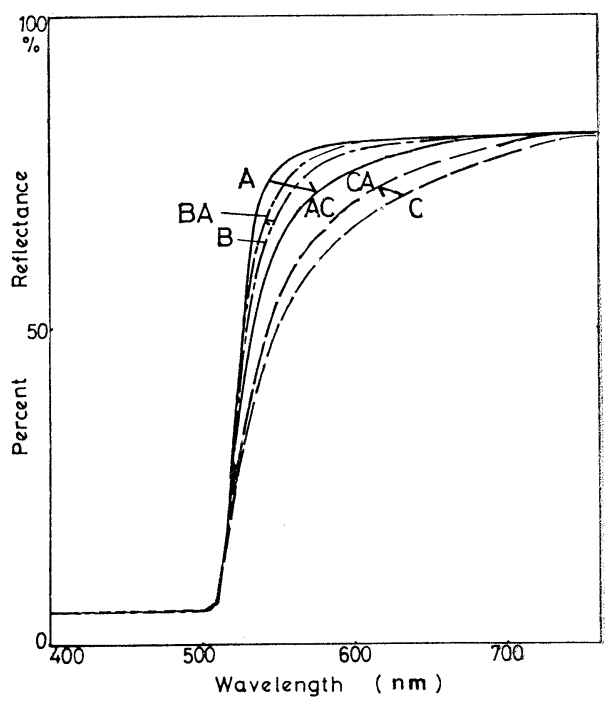

Fig. 3. Differences of spectral reflectance curves between first and second heat treatment 


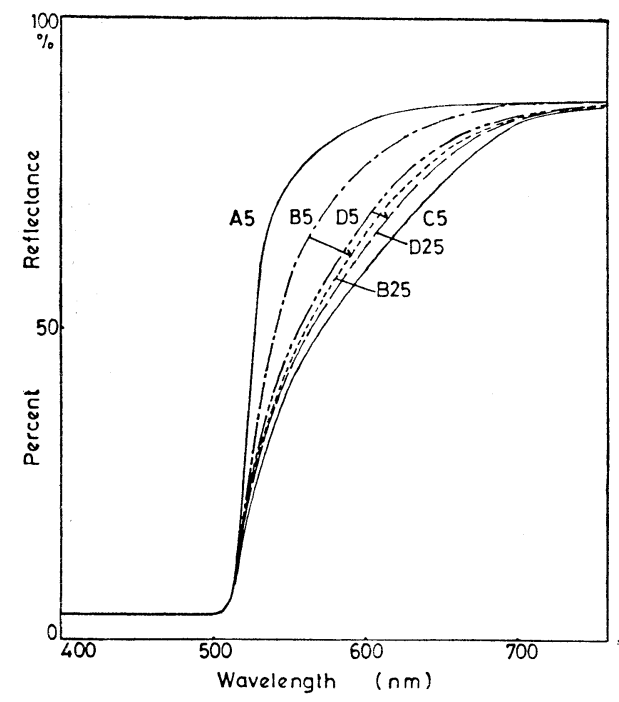

Fig. 4. Effects of the time of heat treatment on spectral reflectance curves

鮮明度への効果は酸素, 窒素, 減圧, イオウの順に低く なる。またこれに対応して色相も暗赤色化していくこと

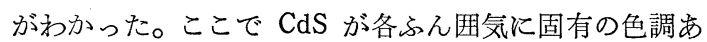
るいは分光曲線を示するのとすれば，その固有值はすで に報告8) したように加熱処理 5 時間後にはほぼ飽和す る。したがって，本実験に执いても表-1 のA，B， C， $\mathrm{D}$ 相当ふん囲気に挌いて 5 時間あるいは 25 時間の加熱 処理を行ない, それら試料の分光曲線の比較を行なった 結果を図-4 亿示した。

この結果, 酸素らん囲気の場合は図-1 の曲線 A（酸 素，1時間）より立上りこう配がやや大となるが，大き な变化ではなかった。また，窒素拉よび減圧らん团気の 場合, 各々程度は異なるが図-1 の分光曲線 C (イオウ, 1 時間）に近づく傾向を示した。さらにイオウふん囲気 の場合は, 曲線 Cのこう配がさらに小さくなる傾向を示 したが変化は小さかった。したがって，酸素ふん团気の みが分光曲線の立上りこう配（すなわち鮮明度）の向上 に有効であることが確かめられた。

\section{2 加熱処理のふん囲気の諸物性への影響}

\section{2 .1 結晶構造}

加熱处理のふえ囲気を変えた試料のX線回折図形を図 -5 に示した。またこれら試料の六方度拉よび格子定数 を表-2 に示した。

これらの結果を総合すると, $700^{\circ} \mathrm{C} て ゙$ 加熱処理した試 料は，ふ九囲気によって色調が大幅に異なっているにも かかわらず，X線回析法によっては核とんど差異が認め られなかった。

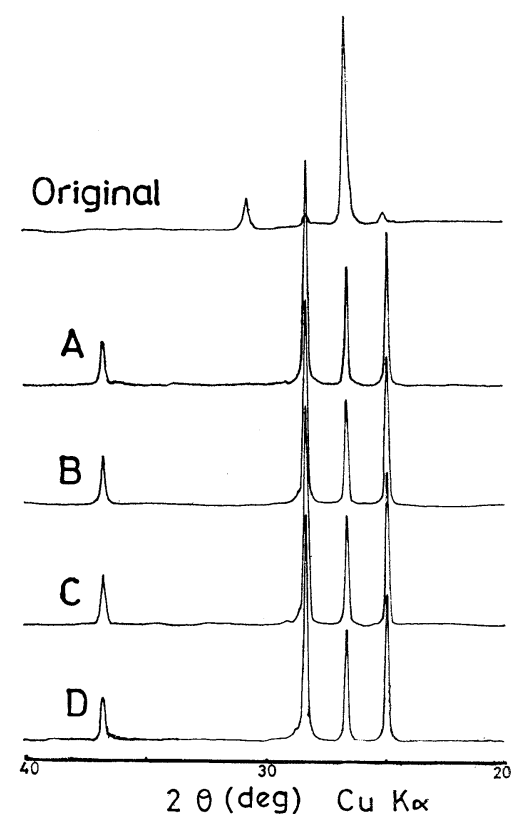

Fig. 5. $\mathrm{X}$-ray diffractometry traces of heat-treated $\mathrm{CdS}$ specimens at $700^{\circ} \mathrm{C}$
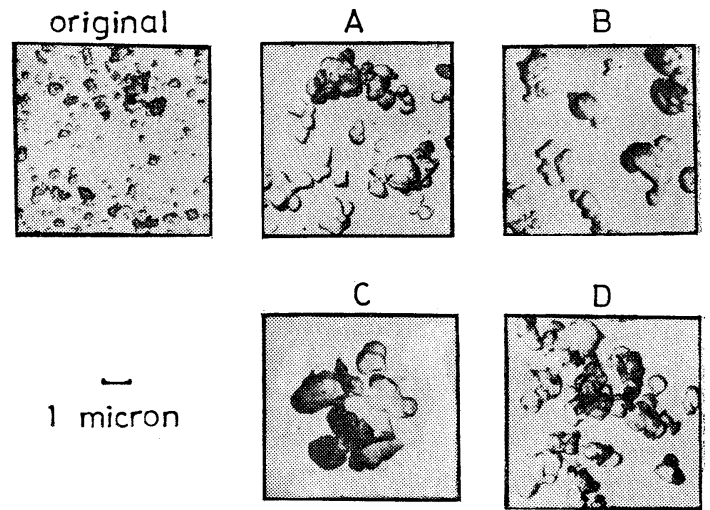

Fig. 6. Electron micrographs of heat-treated CdS specimens at $700^{\circ} \mathrm{C}$

\section{2 .2 粒子の形態}

同じく $700^{\circ} \mathrm{C}$ で加熱処理した試料の電子顕微鏡写真を 図-6に示した。粒子の形と大きさは酸素，窒素特よび 減圧ふ九囲気の場合は洼とんぞ同じであり，平均粒径は 約 $1 \mu$ であった。しかしイオウふん囲気の場合は粒子径 が著しく大となり（約 $3 \mu$ となり）粒子成長に対するふ 几囲気イオウの効果の大なることが明らかとなった。

\section{2 .3 表面状態}

加熱処理のふん囲気による粒子表面状態の差を赤外線 吸収スペクトルによって比較検討した。この結果 400〜 $4,000 \mathrm{~cm}^{-1}$ の範囲に扮いては，全域にわたって全試料 
Table 3. Hexagonalities of heat-treated samples at 500,600 and $700^{\circ} \mathrm{C}$

\begin{tabular}{c|c|c|c}
\hline \multirow{2}{*}{ Sample } & \multicolumn{2}{|c|}{ Temperature of heat treatment $\left({ }^{\circ} \mathrm{C}\right)$} \\
\hline & 500 & 600 & 700 \\
\hline A & 20 & 70 & 95 \\
B & 20 & 80 & 95 \\
C & 60 & 95 & 95 \\
D & 20 & 85 & 95 \\
\hline
\end{tabular}

とも吸収が文られず，差は認められなかった。

また，ガス分析によって減圧 $10^{-5} \mathrm{mmHg} ， 500^{\circ} \mathrm{C}$ に 沶ける脱着ガスを定量した。各試料の吸着ガスの種類お よび量は表-2 に示したようにほとんど差がなく，測定 前後の試料の色調もほとんど変化していなかった。

以上の結果から，各試料の色調の大きな差は表面状態 からは説明できなかった。

3.2 .4 枀方度

加熱処理の温度が $500^{\circ} \mathrm{C}, 600^{\circ} \mathrm{C}$ 执よび $700^{\circ} \mathrm{C}$ の場合 の各試料の六方度を表-3 に示した。

この結果，六方度の向上に対するイオンふん明気の効 果は他のふ九囲気より著しいものがあり, 前述の粒子径 への效果とよく刘応している。一方, 酸素らん囲気に関し ては六方度の向上への寄与は最も少ないことが示された。

3.2 .5 化学組成

加熱処理した試料の S/Cd モル比は，化学分析の結 果, 表-2 に示されるように1〜2モル\%のイオウが化 学量論的当量から不足している。これは Reisman ら ${ }^{18)}$ の測定結果と同程度であり, Cd よりも気化しやすいイ オウが不足となるのは妥当な結果といえる。したがって 試料 $\mathrm{B}, \mathrm{C}, \mathrm{D}$ の鮮明度の低い原因の一つとしてイオウ 不足による構造欠陥があると推測した。また酸素らん囲 気に拈いて再加熱処理することによって鮮明度を増すこ とは, 酸素の結晶内への拡張を示唆するが, この点の確 認はできなかった。

\section{4. 総合的考察}

本実験の結果によって，加熱処理のらん团気がスによ る CdS の色調の著しい差異との傾向が明らかとなった が，その原因すなわら色調と物性との相関を明確にする ことはできなかった。

分光曲線の吸収端の立上りこう配が大きい（鮮明）と いうことは結晶粒子の平均的結晶性が高いということで ある。これと粒子表面と光との相互作用が加わって吸 収, 反射などが起こり, 総合的に色調として現われる。 同一結晶形をもった粉状 CdS に和いては, 結晶欠陷あ
るいは不均一性によって総合的結晶性が変化する。加熱 処理のふん囲気はこれらに対して重要な役割を果たして 特り，本研究によって定性的な効果を明らかにするこが とできた。

一般に顔料としての CdS を考える場合，その製造過 程に扮いては粒子径を $0.1 〜 0.5 \mu$ に抑えたまま結晶性 （鮮明度）の向上をはかることが最も重要なことである。 この観点からい党ば酸素らん囲気は加熱処理の時間, 温 度が同一の場合には，粒子径を特に成長させることな く, 他のふえ囲気よりも最も容易に鮮明な色調の CdS を得るのに有効である。これは実用上非常に大きな利点 となる。

しかしながら，このときの結晶特性, 粉体特性と顔料 特性との相関性の解明はできなかった。これに関しては 今後の課題としたい。

\section{5. 結 論}

$5.1 \mathrm{CdS}$ の色相は結晶多形の $\alpha$ 型と $\beta$ 型の混合比率 によって変化し， $\alpha$ 型は $\beta$ 型より黄味である。

5.2 結晶性の高い $\beta$ 型 $\mathrm{CdS}$ の高温安定型の $\alpha$ 型への 多形転移は, 加熱温度が $500^{\circ} \mathrm{C}$ を越光ると急速に進行 し， $700^{\circ} \mathrm{C}$ ではほぼ $\alpha$ 型に転移する。

5.3 加熱処理のふえ囲気の変化によって CdS の色調 は大きく変化する。特に鮮明度は酸素, 窒素, 減圧, イ オウの順に低下し，これに伴って色相も暗赤色化する。

5.4 ふ九囲気の効果は, ふ九囲気を変克て段階的处 理をした場合も同じ傾向を示し，最終らん囲気の色調に 近ついていく。

5.5 加熱処理時に和いて, ふ九囲気イオウは粒子径 と六方度の増加に対して有効である。一方，ふ九四気酸 素は粒子成長に対しては窒素, 減圧とほぼ同じ効果を示 すが，六方度の向上に詨してはもっとも効果が少なかっ た。

5.6 鮮明な色調の $\mathrm{CdS}$ を得るためには酸素の存在が 必要であった。

$$
\text { 文献 }
$$

1）佐藤亮一郎：応物，35, 388 (1966)

2) A. J. Eroles and A. L. Friedberg: J. Amer. Ceram. Soc., 48, 223 (1965)

3）山内俊吉, 遠藤幸雄 : 弿協, 60, 417 (1952)

4) P.Cherin, E. L. Lind, E. A. Davis : J. Electrochem. Soc., 117, 233 (1970)

5) W. M. Kane, J. P. Spratt, L. W. Hershinger, I. H. Khan : J. Electrochem. Soc., 113, 136 (1966)

6) 綱島 真, 毛利慧三, 堤 和男, 高橋 浩: 工化, $74,1733,1740$ (1971) 
7）綱島真，堤和男，高橋浩 : 日化, 1, 817(1972)

8）綱島真, 高橋浩 : 日化，1，1788，1794（1972）

9) E. H. Weber: Phys. Stat. Sol. (a), 1, 665, (1970)

10) J. P. Legré and S. Martinuzzi : Phys. Stat. Sol. (a), 1, 689 (1970)

11) R. Shubert and K. W. Böer : J. Phys. Chem. Solid, 32, 77 (1971)

12) V.S. Babinchuk and V. V. Serdyuk: Phys. Stat. Sol. (a), 6, K 81 (1971)

13) D. S. Drr, L. Clark, J. Woods : Brit. J. Appl. Phys., Ser 2, 1, 1609 (1968)

14) L. Deweritz and A. Messerschmidt : Phys. Stat.
Sol. (a), 4, K 193 (1971)

15) R. Ludeke : J. Vacuum Science and Technology, 8, 199 (1971)

16) M. Hársy, J. Balázs, P. Sviszt, B. Pödör, E. Lendvay : J.Crystal Growth, 9, 209 (1971)

17) L. Clark and L. Woods : Brit. J. Appl. Phys., 17, 319 (1966)

18) A. Reisman, M. Berkenblit, M. Witzer : $J$. Phys. Chem., 66, 2210 (1962)

19) M. A. Short and E. G. Steward: Amer. Mineral., 44, 189 (1959)

20） JIS Z 8701, 色彩科学協会, “色彩科学ヘンドブ ック，南江堂 (1962) p. 96.

\section{色 材 協 会 誌 Vol.47 No.7 (予告)}

報文

有機顔料の耐熱性 (1)

$\beta$-ナフトール系顔料の熱分解機構と耐熱性 武蔵工業大学 西 川 登志子他

膨潤伸長法によるメタクリル/メラミン系樹脂の橋カケ反応 に関する研究（第 2 報）………………………………日本ペイント(株) 出 雲 孝 治他 エポキシ樹脂分散系の安定性に及ぼす界面活性剤の影響……………...菱電機(株) 地 大 英 毅他

\section{テーマ資料}

感光性樹脂扔よびその慜版システムの開発と工業化………………旭化成工業(株) 甲 斐 常 敏 特許 公 告

文献 